\title{
LANGUAGE AND IDENTITY: THE BLACK MINORITY OF COSTA RICA
}

Anita Herzfeld

\begin{abstract}
In this paper I argue that while social identity and ethnicity are in large part established and maintained through language, it is because of the sociohistorical character of the process through, which a group's language is evaluated that a subordinate people's language will either survive or become extinct as a symbol of identity. Furthermore, in the case of Limonese Creole speakers who live in Puerto Limon, Costa Rica, given the climate of socioeconomic distress that the region is undergoing, they feel more self conscious than ever about their "broken" English. While at other times is history their creole could well have acted as a symbol of linguistic rebellion conducive to feelings of group solidarity, at present it is clearly considered a liability.
\end{abstract}

\section{Introduction $^{1}$}

In this paper the English-based Creole spoken by the Limonese BLACK minority of Costa Rica will be used as a case study to explore the salience of language as a dimension of ethnic identity. While many scholars (e.g., Fishman 1977, Gumperz 1982, Giles 1977) consider that the possession of a given language is of particular relevance --almost essential-- to the maintenance of group identity, others (e.g., Edward 1985) claim that it is important not to lose sight of its non-unique status as a marker ${ }^{2}$. I will argue that while social identity and ethnicity are in large part established and maintained through language, it is because of the sociohistorical character of the process through which a group's language is evaluated that a subordinate people's language will either survive or become extinct as a symbol of identity ${ }^{3}$.

Members of a linguistic community may derive feelings of pride or shame from their perception of the degree of standardization their language has undergone; thus the prestige value attached to the language's of their history may facilitate or inhibit the vitality of a given ethnolinguistic group (Giles 1977: 312). It is my contention that nowadays, given the climate of socioeconomic distress that the region is undergoing ${ }^{4}$, Limonese Creole speakers feel more selfconscious than ever about their "broken English". While at other times in history, their creole could well have acted as a symbol of linguistic rebellion conducive to feelings of group solidarity, at present it is clearly considered a liability. 


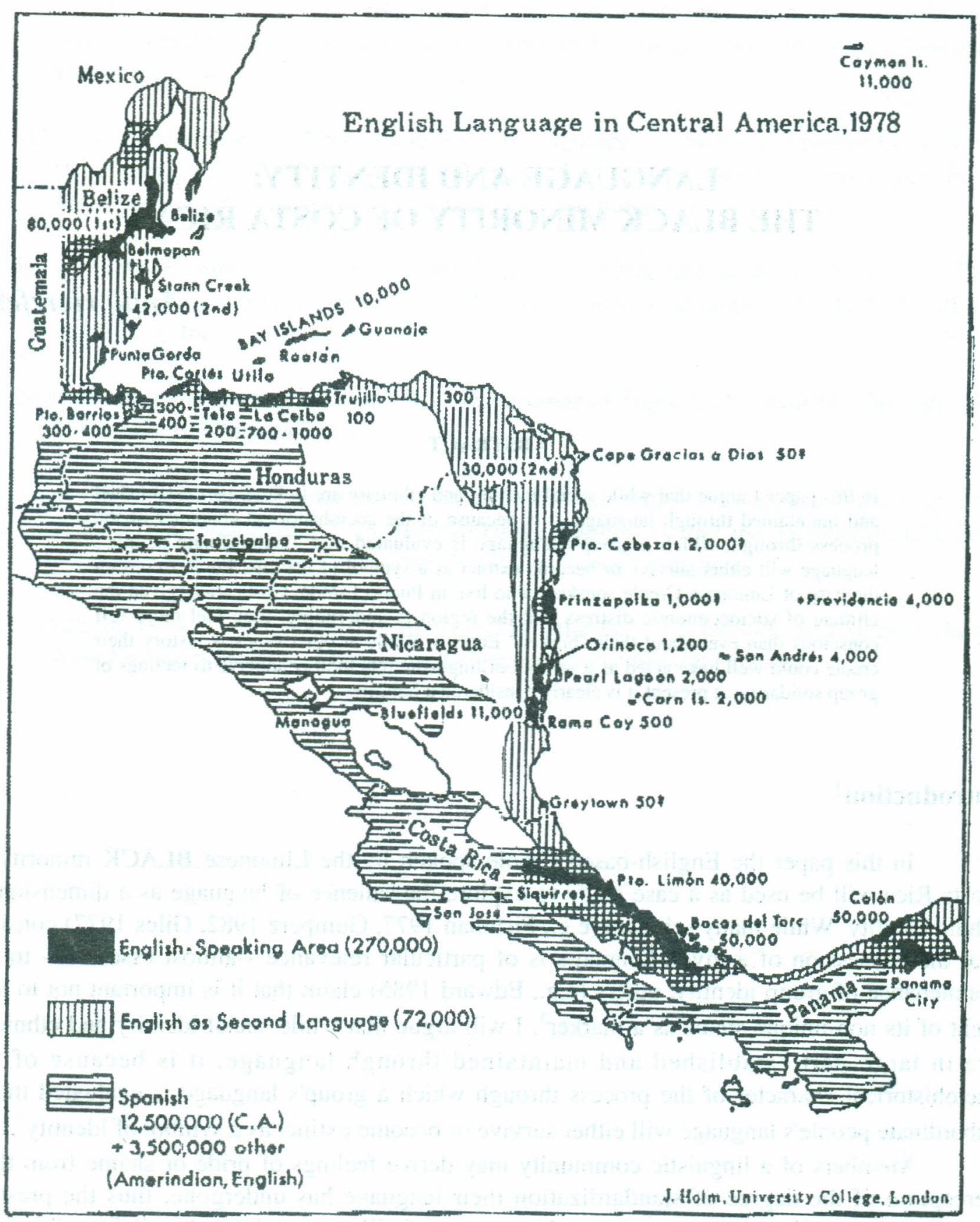

Fig. 1. Map showing the spread of English Creoles in Central America. Source: Holm, John ed., Central American English (1983: 8). 


\section{Dimensions of Language and Ethnicity}

Attempts to analyze the relationship between language and identity have focused foremost on the relationship between language and ethnicity. Language is a highly structured and sophisticated system which, with subtlety and flexibility, is crucially related to a human being's most significant capacities, thought and cognition, including the ability to, categorize, classify and symbolize. Ethnicity, on the other hand, comprises a number of concepts because of the many interrelated factors that it subsumes. At a simple level, ethnicity can be thought of as a "sense of group identity deriving from real or perceived common bonds such as language, race or religion" (Edwards 1977: 254) .

In those general terms, ethnicity is based on a collectivity's self-recognition. It differs from other kinds of group recognition signals in that it operates basically in terms of what Fishman (1977: 16) calls "paternity"6 rather than in terms of "patrimony"7. Through ethnicity individuals not only attain social integration, but they are also linked to social norms and values, to a certain Weltanschauung, to inherited and acquired both stable and changing notions of society and the world. It is easy to see why language, one of the essential characteristics of human behavior, is associated with ethnic "paternity". Moreover, because one can exert more control over one's linguistic behavior (more than over other dimensions of ethnic identity), language is seen (and heard!) by others as "a truer reflection of one's ethnic allegiance" (Giles 1977: 326). However, since the course of language is dynamic, it is also very susceptible to change as an element of identity, inextricably linked as it is to the social determinants of human life.

Indeed, in the history of humankind nationalism records its strong link with language and identity from the moment of its modern inception. Largely a product of German romanticism of the late eighteenth and early nineteenth century, both Herder and Fichte and a little later Wilhelm von Humboldt felt that nothing was more important for national culture and continuity than possession of the ancestral tongue . $^{8}$

On many occasions language became a tool for achieving nationalistic goals. The idea of linguistic nationalism was a dangerous one, however, when it equated language and race. Although the power of language is undoubtedly a factor in nationalism, Smith (1971:149-150) has made the useful point that emphasis upon language follows the growth of nationalist fervor; it does not create it.

\section{Languages in Contact}

Multilingual societies are found in all parts of the world; they existed in the past and they occur today; they are found in older nations as well as in the newly-created states. Currently, for instance, there is more than one viable language in each Latin American country. The political and social situation created by this linguistic diversity ranges from the quasiperfect harmony of Spanish and Guaraní in Paraguay to Guatemala or Peru', where the entire political fabric is torn into factions which often coincide with linguistic boundaries. Even in 
those societies where equality between linguistic groups would seem to have been achieved in official political terms, it is rare to accomplish it either in the social or economic sphere. To complicate matters further, linguistic differences often become associated with racial or ethnic differences, thus making the language contact situation a hopelessly entangled one (Lieberson 1981:1). Generally speaking, speakers of diverse languages do not come into contact under neutral emotional conditions; more often than not the contact situation involves some kind of dominance of one group over the other, thus always producing significant attitudinal reactions.

In studying the relationship of language and identity within a bilingual/multilingual nation, it is important to examine the history and nature of the contact situation between the peoples who speak diverse codes, whether dialects or languages. One fundamental step is to distinguish groups which are politically and economically superordinate from those that are subordinate in these institutional domains (Lieberson 1981: 2), and how such a differential power relationship was created. Likewise, one should also distinguish between migrant and indigenous populations at the time of their contact, "indigenous" referring to groups with established social institutions --not necessarily the earliest groups known to have inhabited a given area $^{10}$. From these distinctions, one can develop a rudimentary theory which suggests that the course of language and identity will be different in settings where the indigenous group is subordinate as opposed to those where the migrant populations are subordinate.

When two distinct linguistic groups come into contact, we may find a situation in which (1) the indigenous group is superordinate, (2) the migrant group is superordinate, (3) the indigenous group is subordinate, (4) the migrant group is subordinate, and (5) neither group is superordinate in all domains. The languages spoken by group (1) or group (2) are not likely to shift, if these speakers are dominating the political and economic spheres of a country. The superordinate group may decide in favor of keeping the languages of the groups in contact as their strategy for achieving their goals (policy which is likely to bring about multi/bilingualism); or in favor of making their language the oficial language (in which case monolingualism of the dominant language obtains). Indigenous subordinate groups (3), on the other hand, may be placed in a condition where they are not permitted to maintain their language (which results in monolingualism of the dominant language), or where they are permitted to use their language solely in private domains (a situation which creates diglossia) ${ }^{11}$. Alternatively, they may enter a self-segregation condition in which they refuse to learn the dominant language (monolingualism of the subordinate language is the consequence) ${ }^{12}$.

The linguistic situation of urban Paraguay is certainly unique ${ }^{13}$, there Spanish (from the descendants of the colonizers) and Guaraní (from the Tupí-Guaraní Indians) seem to coexist by side, illustrating situation (5) above and what Fishman (1972: 91-106) calls "a stable bilingual society"14.

Migrant subordinate groups (4), by contrast, seem to show a relatively rapid rate of linguistic and identity shift ${ }^{15}$. This is the case of the Limonese Creole speakers of Costa Rica, the subject of the remainder of the paper. As we shall see, Jamaican Creole speakers migrating from their own established social order to a setting of subordination in Costa Rica brought about their need to assimilate or adapt to the new order. In a non-symmetrical culture contact situation such as this one, varying degrees of socio-structural and socio-psychological acculturation took place under the considerable pressure exercised by the superordinate group. 
Language played an important role as the vehicle for acquiring the new culture; it was, in fact, the most important element acquired in the quest for new identity.

\section{Pidgins and Creoles}

As mentioned above, when two peoples who speak different languages come into contact, one of the most common solutions used to establish communication is for the subordinate group to give up its native tongue. If the European and African contact prior to the 15 th century, for example, had proceeded along non-exploitive terms, the usual foreign language learning process would have led to some Africans speaking European languages fluently, others speaking them passably, and still others having only a smattering (Bickerton 1975: 175). The slave trade disrupted this pattern, isolating many Africans ${ }^{16}$ from their own speech communities and truncating their acquisition of a European language. Some creolists would say that this left them with the ability to speak their own native tongue(s) as well as with an imperfectly acquired European language. ${ }^{17}$ The need to communicate amongst themselves produced a pidgin which is commonly defined as:

a reduced language that results form extended contact between groups of people with no language in common; it evolves when they need some means of verbal communication, perhaps for trade, but no group learns the native language of any other group for social reasons that may include lack of trust or of close contact.

(Holm 1988: 5)

Usually, this makeshift language borrows vocabulary from the superodinate language, although the structure and meaning may be strongly influenced by the subordinate language(s). A few conditions must be fulfilled for a pidgin to be constructed: (1) a real need for communication among the groups must exist, not for all circumstances but in limited contact situations, (2) social distance between the superordinate and the other languages must be maintained (otherwise the subordinate groups would learn the superordinate language!), (3) the languages in contact are probably not closely related, otherwise koineization (or dialect levelling) would result. By definition the resulting pidgin must be easy to learn, i.e., it is a simplified language (with no inflections, for instance), it has a reduced vocabulary, and it is restricted to limited semantic domains (trade, for example, in which case it is considered a lingua franca).

The pidgin is a kind of "foreign" language --of limited vocabulary and restricted syntactic alternatives-- to which each pidgin speaker adds his/her influence in different ways (i.e., each speaker's mother tongue differentiates the use of the pidgin in a distinctive way). The children born in the New World to African pidgin-speaking parents, for instance, found the pidgin (however variable) more useful than their parents' native languages (Holm 1988: 6-7). Thus, when a pidgin develops into the native language of an entire speech community it 
becomes a creole. To the inherited pidgin language developed under the social disruption suffered by the speakers' ancestors, creole speakers add some enlargement and organization, in response to communicative needs. Basically the process of creolization or nativization, which is the opposite of pidginization, entails the expansion rather than reduction of the language, the elaboration of the vocabulary, and a complex reorganization of the grammar. As a result of the geographic displacement of the speakers and the broken ties with their sociocultural identity and their original language, their sociolinguistic history, and not just the structure of their language, is an important determinant of the linguistic outcome in these types of language contact situations.

\section{Limonese Creole}

Even though our social identity is established by the parameters and boundaries of our ethnicity, gender, and class, once we study language as the interactional discourse of that social identity, we find that these parameters are not constants that can be taken for granted, but are communicatively produced (Gumperz 1982:1). Therefore, to understand issues of identity and how they affect and are affected by social, political and ethnic divisions we need to gain insight into the communicative processes by which they arise. However, communication cannot be studied in isolation; it must be analyzed in terms of its effect on people's lives. Thus in what follows rather than concentrating on the grammar, semantics, or linguistic variation of Limonese Creole, I will take up the ethnohistory of its speakers, analyzing situated talk in the perspective of sociolinguistics.

\section{General Information on Costa Rica}

Costa Rica has always been advertised as the Central American country with "more teachers than soldiers," "the Switzerland of Latin America," the country of "eternal spring," "the garden of the Americas"; moreover, it prides itself on being much more homogeneous than other Central American nations--ess Amerindian, and almost entirely Catholic and Spanishspeaking.

Commercial publicity slogans hide the real richness of the country: its unique racial and complex social make-up and its natural beauty. In reality, many ethnic groups have made their home in Costa Rica belying the claim of homogeneity; and its tropical rain forests, beaches, volcanoes and national parks deserve to be enjoyed and praised in their own right. While the country has maintained an admirable history of civilian governments, it is by no means affluent. Linguistically, however, it is rich: in addition to the different dialects of Spanish that are spoken, there are speakers of at least five indigenous languages ${ }^{18}$, and a BLACK minority uses an English-based Creole, which I have called Limonese Creole (hereafter LC), known by its speakers as/mekaytelyuw $/{ }^{19}$. As will become apparent later, LC can be best described as a linguistic continuum that stretches from a West Indian English-based Creole to 
Standard Limonese English (SLE); it is spoken in the Province of Limon, on the Atlantic lowlands of Costa Rica (see Figure 1), by a BLACK minority of mostly Jamaican origin.

Of the seven provinces in which the country is divided, Limon is markedly distinguishable from the rest in every sense--in terms of its geography, history, economy, its people and their culture. None of the typical Costa Rican traits are to be associated with Limon. Although the composition of the population has changed considerably since Bryce Laporte (1962: 2) studied it thirty years ago, his remarks about its idiosyncratic character are still true:

\begin{abstract}
Limon...continues to be an anomaly among the provinces of Costa Rica but remains typical of sociocultural life in the Western Caribbean coastal and insular societies of Central America. Thus it is characterized presently by a sort of hybridization of Antillean Negro and Hispanic American cultures.
\end{abstract}

The province is inhabited by several ethnic groups drawn to the area by banana plantations. These have attracted businessmen from Europe and the United States as well as Chinese, ${ }^{20}$ Amerindians, Coolies ${ }^{21}$, Blacks and /panya/("Spaniards," as the Limonese BLACKS call the native White Costa Ricans and other Central Americans). The BLACKS and "Spaniards" constitute well over 90 percent of the population of the Province of Limon, which totals close to $200,000^{22}$.

The capital of the province is called Puerto Limón. It is a port in what Augelli (1962) calls the "Rimland"--a region of islands and coasts washed by the Caribbean and economically dominated by its paramount commercial and naval power. When travelling by bus to the coast from the capital of the country, San José, (which is located 103 miles away on a central plateau (Meseta Central), one follows a winding road along sinuous mountain paths, while an incredible succession of natural beauty parades by the window.

\title{
The Limonese: Ethnohistorical Background
}

LC is spoken by a BLACK minority of approximately 40,000 people. The BLACKS have constituted a segment of Costa Rican society for over 400 years. They have lived mostly in the Province of Limon, while Costa Rican society and culture tends to be considered as existing only in the highlands. This dichotomy, which has been very significant throughout the entire history of the country can be seen in Carlos Meléndez's outline of the basic structures of both cultures (Table 1, 1974: 48).

The ethnohistory of Limonese BLACKS can only be understood vis-à-vis the history of Costa Rican society itself. For that purpose, Michael D. Olien, in his study "The Negro in Costa Rica: an [sic] Historical Perpective", points out three major structural changes in Costa Rican society which resulted in important alterations in the position of the BLACKS: 
Table 1

Comparative cultural structures

Institutionalized

Activity
Structure valid

for the Black

Antillean group
Structure valid for the Costa Rican group of the Central Valley

Spanish

Matrilineal, com-

mon law marriage

Subsistence

agriculture

Laborer

Tubers, bread-

fruit, coconut

Protestantism

Magic

Elaborated

Church Schools

Baseball

Dominoes

United Negro

Improvement

Assn. Lodger

Musical events
Patrilineal

Formal marriage

Commercial

agriculture

Proprietor

Rice, beans

tortillas

Catholicism

Non-orthodox beliefs

Simple

public School

Soccer

Sport clubs

Church

Fairs (turnos)

Carnivals

Source:

Meléndez, Carlos. "Introducción a la Cultura Negra", 1974: 48 (my translation).

1. the polarization of power which took place during and after the colonial period (1570-1870); 2.the de facto control of the lowlands exercised by the United Fruit Company (1879-1948) and 3. the legal and social reforms brought about by the 1948 Revolution (1948 to the present)

Correspondingly, Olien distinguished the existence of three "types" of BLACKS, each type to be assigned to one of the above-mentioned time periods, respectively: 1. the African 
BLACK, 2. the West Indian BLACK, and 3. the Costa Rican BLACK. His thesis being that these types represent different adaptation patterns to Costa Rican society at different points of time, he concludes that there is no evolutionary sequence or continuity from the first to the second period--miscegenation was important during the colonial period and separatism during the United Fruit Company (UFCo.) period. The opposite is true about BLACKS living at the end of the second period into the third: acculturation and assimilation have become important to them. Linguistically, however, a West Indian heritage can still be traced back for BLACKS of the third period.

Whereas African BLACKS constituted the slave labor force in the lowlands during the Spanish colonial period, ${ }^{23}$ the West Indian BLACKS of the United Fruit Company's period of lowland domination were primarily Jamaican peasants. (See Table 2, and map, Figure 2, next page).

By the mid-nineteenth century, Costa Rica had gained independence. There was no longer a Spanish government that considered trading with the British illegal and the highlands produced coffee, a bulky product that needed to travel to England. However, the good road for exporting it went in the opposite direction--west, to Puntarenas. Freight rates were twice as high for shipping coffee to England from Puntarenas as they would have been had it been exported from an Atlantic port. Costa Rican coffee growers decided to invest in a railrcad to the Atlantic.

Minor C. Keith, an enterprising North American, was commissioned in 1872 to build a railway from San José, the capital, to the Atlantic coast, so as to permit coffee shipments to Europe. The construction of the railroad attracted intermittent waves of workers, especially from Jamaica, although a few others came from Barbados, Trinidad, Haití, and even New Orleans, and many others from Jamaica but via Bluefields (Nicaragua) and Panamá (Stewart, 1964: 36,65).

The rural Jamaican subculture which the original migrants carried with them to Costa Rica constituted a part of the end result of a complex process of integration of the African and British cultures into a new creole culture. This new culture was constantly undergoing modification to meet the limitations and demands that followed the passage from slavery to emigration. Most sources that deal with this topic attribute to Minor C. Keith a further feat: in order to struggle against some of the discouraging financial factors, he decided to introduce the commercial planting of bananas. The presence of Jamaicans --a banana eating people who had previous experience in the cultivation of the fruit-- certainly contributed to the success of the enterprise that was soon to replace the railroad in importance. Keith formed the United Fruit Company in 1899.

Many Jamaicans who had originally emigrated to work temporarily on the construction of the railroad, decided to stay on and work for the Company, on the plantation or at the port, which was Campany owned as well. The plantation system was to permeate all aspects of their lives. All needs of the workers were, from then on, fulfilled by Mamita Yunai ${ }^{24}$. It was a selfcontained system, with the train as the backbone of communication in the region. The BLACKS lived in Company-owned houses; they bought their goods at the Company stores; they sent their children to Company-sponsored English schools. The Company was then, (and many other multinational companies are today), responsible for the ecological, agricultural, 
Table 2

Estimated net emigration of Jamaicans: 1881-1921

$\begin{array}{ccc}\text { Period To USA To Panama } & \text { To Cuba } \\ \text { Areas, } & \text { To Other } \\ \text { Especially } & \text { Costa Rica }\end{array}$

$\begin{array}{lrrrr}1881-91 & 16,000 & 17,000 & 10,000 & 43,000 \\ 1891-1911 & & 26,000 & & 26,000 \\ 1911-21 & 30,000 & 2,000 & 22,000 & 23,000\end{array}$

Source: Roberts, George: The Popolation of Jamaica, 1957: 139.

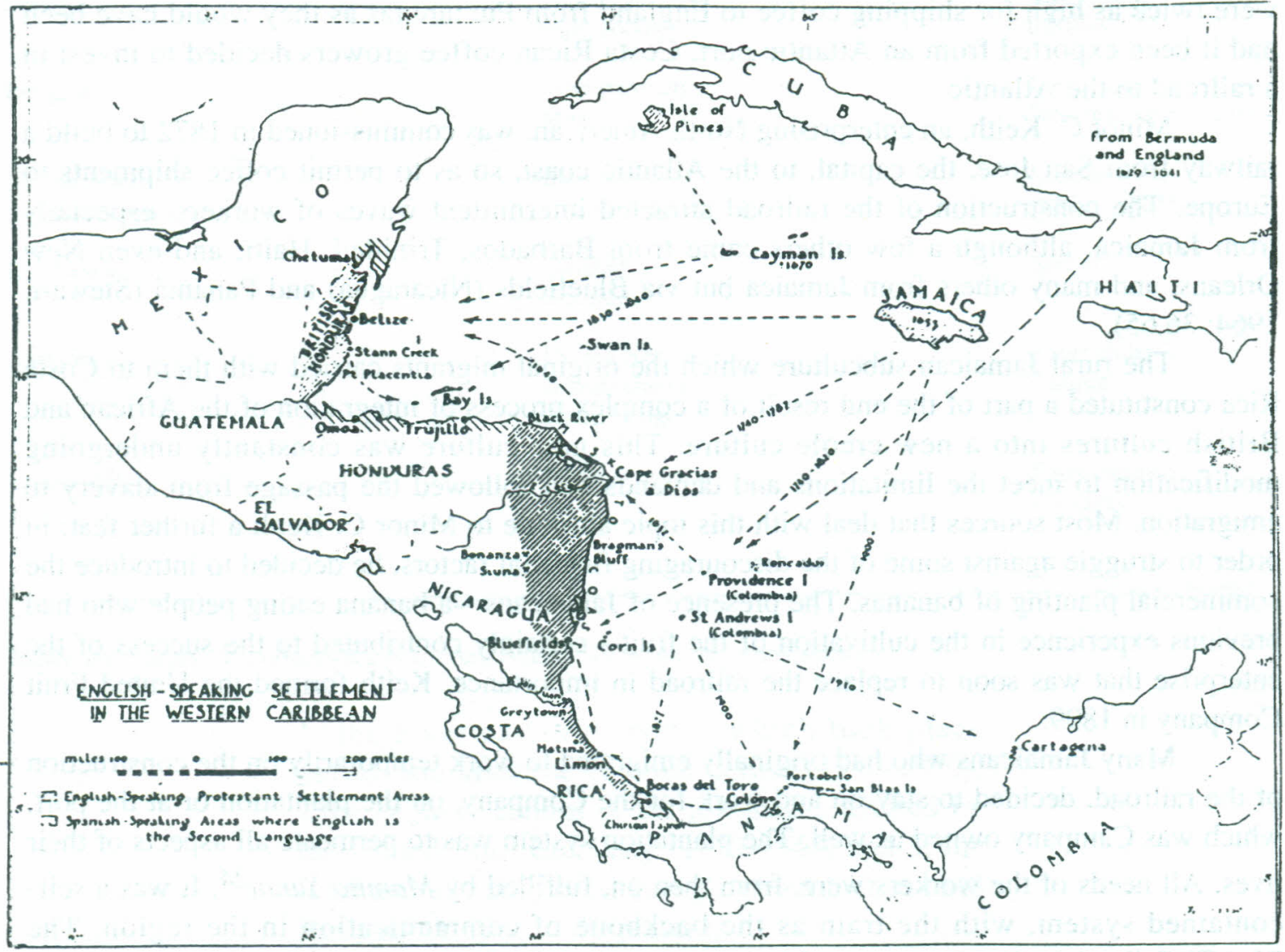

Fig. 2. English-speaking settlement in the Western Caribbean. Source: Holm, John, ed., Central American English (1983: 6). 
economic, cultural and social peculiarities of the province. Since the de facto government of the lowland was exercised by the Company, people's lives depended on it.

Conceived in the typical pattern of plantation economy, the two migrant groups (managers and workers) transitorily settled down to carry on operations that were to bring about profitable production of agricultural staples--the profit necessarily going to the foreign investors. This type of institutional arrangement facilitated the unhampered use of coercion on the part of the managers and fostered the existence of a politically powerless group, the workers, who were entirely controlled by the Company and had no direct dealings whatsoever with the Costa Rican government. The Company only allowed the BLACKS to hold middle and bottom hierarchies. For the West Indian BLACK the plantation system remained static; limited to the context of restricted regional opportunities, established foreign authority, and white prestige hierarchy.

Since the government of the lowlands was exercised by foreigners, the West Indian BLACKs process of acculturation and assimilation to Costa Rican culture and society was slowed. The workers as well as the managers, introduced their languages--Jamaican Creole and American English--as the everyday languages in their community. The BLACKS who had been acculturated to British West Indian culture and were "English"-speaking Protestants found it very easy to comply with their managers' pressure to maintain both their language and their religion. Obviously they were encouraged to do so.

As the Company's gains increased, other nationality groups--East Indians, Chinese, Syrians, Europeans, U.S. Whites, and Central Americans-- started drifting into the once mostly predominantly BLACK Jamaican Limon. Contrary to expectations, the pluralized cultural complexity that developed--which would have implied greater cultural contacts, conflicts, exchange, and a faster acculturation-- only served to mitigate adaptation. No national ideas or Costa Rican sentiments had been pressed on the BLACKS; they preferred to maintain their own ethnic group; their houses remained separated from everyone else's; and they kept in touch with their kin through Jamaican newspapers. They were hoping to go back "home" and prepared their children for that return; they sent their earnings to Jamaica and visited their native country frequently--by Company's boats--and were encouraged to return there when they grew old (Le Page, 1960: 104).

At the end of this period, when the U.F. Co. folded on the Atlantic coast in 1942, there was an increasing emphasis on social differences and decreasing importance of national or even racial differences. The pervadig picture of unity among the West Indian BLACKS in Limon started then to break down to give way to a rise of native Costa Rican prestige and power groups. However, there is continuity in another sense: while the relationship between the ethnic identity of BLACKS of the colonial period and that of West Indian BLACKS was discontinuous, the ethnic identity of what Olien calls the Costa Rican BLACK (1971: 98) can be traced back to that of West Indians BLACKS that had settled down in Limon by 1948.

Once outside the plantation system, BLACKS began to adopt Costa Rican customs. First the process of acculturation and assimilation proceeded at a slow pace, but gradually the "West Indian BLACK" was transformed into a new cultural type. Although racially distinct from other Costa Ricans, LIMONESE BLACKS became citizens of the country, started sending their children to public schools learned how to speak Spanish, and in some cases, even became 
Catholics. Although their lack of influence in the power substructure made them lose certain economic advantages, the new socioeconomic distribution, it was hoped, would place BLACKS in the working class and in the newly-emergent middle class. The Revolution of 1948 was seen by people in Limon as the lever that would help BLACKS rise in social status, due to sweeping constitutional reforms. Such was, supposedly, the law that granted BLACKS rights equal to those of all other Costa Rican citizens, so that they could consider Limon their real home.

Actually, there has been considerable structural change in Costa Rican society since the Revolution of 1948, and the position of BLACKS in that society has gone.

from that of "foreign laborer" on foreign-owned banana plantations to that of "Costa Rican," filling positions at the middle and bottom of the wealth, authority and prestige substructures.

(Olien, 1977:153).

It is true that during the first three decades after the 1948 Revolution, Costa Rican BLACKS went through the strongest immersion in Costaricanization ever. Until then, the European--based standards of the Jamaican BLACKS prevailed--only things British had merit. Afterwards, however, a twofold reaction to the old view set in: on the one hand, there was an active trend toward admiring everything that was creole ${ }^{25}$ and at the same time, there was pride involved in participating in national Costa Rican issues.

Socioeconomic changes ensued as well: a redistribution of wealth allowed many BLACKS to become landowners; a fair number were appointed to important public and private positions (such as members of municipal councils, high school principals, town hall executives, JAPDEVA's managers, on the one hand or St. Mark's School principals, MUCAP local managers, on the other) ${ }^{26}$, and their voice and vote assured them some steady continuity of federal representation in the National Assembly. It is even very likely that the visitor at that time would have walked away with some pleasant and memorable impressions of the picturesque market, the typical wooden constructions, the contrast between the people in the meseta central and the coast, and the cosmopolitan atmosphere of the city ${ }^{27}$, but things have changed of late.

During a recent visit I made to the field (December 28, 1992), it became apparent that the October 1991 earthquake not only demolished part of the city and the entire coast of the Valle de la Estrella, but it also brought about a defeatist attitude. Puerto Limon's shabby houses, propped-up cracked cement buildings, and piles of unremoved rubble stand witness to the subhuman living conditions and the ongoing frustration and hopelessness within which the Limonese people survive, as well as to the rapid deterioration that their social fabric has suffered in the last few years.

Four main socio-economic events have altered the composition and racial profile of Puerto Limon ${ }^{28}$ : (1) the construction in 1975 of the first highway to join the port with San José; (2) the great influx in the 1980s of White refugees from the wars in Nicaragua and El Salvador $^{29}$ (3) the Costa Rican government's newly-adopted economic policy of neoliberalism in compliance with directions issued by the International Monetary Fund's for Latin America, 


\section{FIGURE 3}

Costa Rica's International Migration to the Atlantic Region 1968-1973

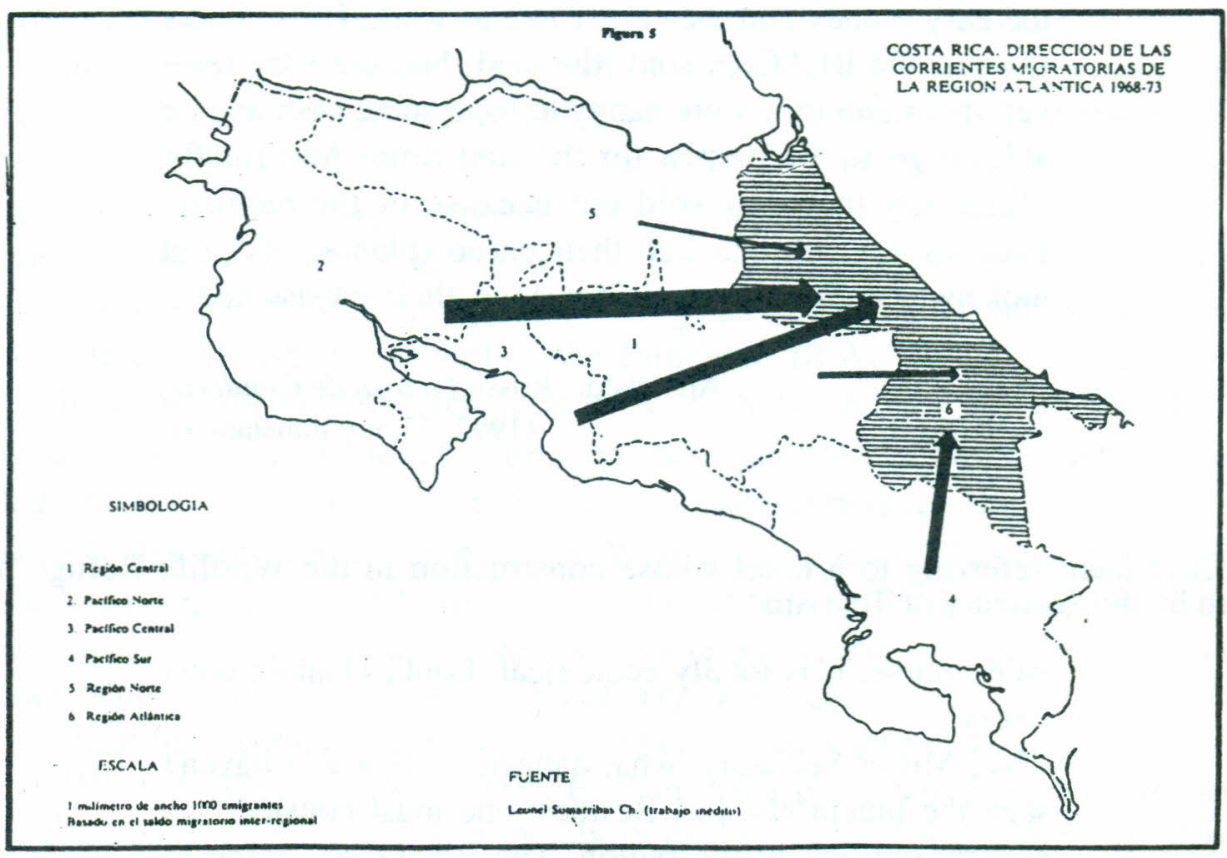

Source: Carvajal and Driori 1987: 45

and consequently, (4) due to rising unemployment, the increasing search for labor opportunities on the Atlantic coast. (See Figure 3).

Even a brief glance at today's reality is enlightening. During my recent visit, I observed that out of 30 or so passengers on the bus service that links the capital with Port Limon, only 2 were BLACK ${ }^{30}$. Once the bus left the road built through one of Costa Rica's most beautiful National Parks, Braulio Carrillo, I could see that the once lush tropical rain forests had been replaced by hundreds of hectares of banana plantations owned by multinational corporations ${ }^{31}$. As Anacristina Rossi puts it in her latest novel, albeit referring to the Atlantic coast Gandoca Refuge:

There are many versions on how and why they [the inverstors] arrived. Some say it was inevitable, that the rumor had spread that the beaches were perfect. That such beauty could not be kept a secret forever.

Sangle others say it was the road, that without the road, the beauty would have remained hidden. Others say it was the greediness of the white man, that the Whites told 
the BLACKS cunning lies: "Sell your land because since it is within the Refuge, soon you will not able to farm there." Others, the greatest racists, say that the BLACKS are like that, that they sell everything because they like the easy money and they don't like to work. Even others say that the BLACKS sold [the land] because they were very poor and they were happy to have some cash and be able to go to the dentist for the first time. And finally others say that they sold out because of the monilis [sickness] which attacked their cacao (plantations) and took away their one source of income, their subsistence.

Anacristina Rossi, La loca de Gandoca

(1992: 37, my translation).

And later, referring to a hotel whose construction in the Wildlife Refuge had been approved by the Secretary of Tourism:

--Of course, it is totally ecological. Look, Daniela don't worry!

--No, Mister Secretary, what happens is that you haven't seen the blueprints. [...] Besides, one must consider the general outlook of the region. The Blacks are going to turn from owners intoservants.

--Look, Daniela, between you and me, what are you going to have the Blacks do if not work as servants?

Anacristina Rossi, La loca de Gandoca

(1992: 47).

How has this briefly sketched economic picture affected the BLACKS? Originally farmers, railroad workers, and plantation laborers, the members of the BLACK minority have taken a long time to enter the competitive market ${ }^{32}$.Although there are some successful professionals among the Limonese BLACKS of today, and a few have been given key managerial positions, for the most part they are common laborers, small farmers, and stevedores. Very few manage to obtain anything but temporary jobs (which, although they pay reasonably well, produce psychological instability, and the hard physical labor of these jobs soon wears out the individual). Consequently, emigration has been one solution to the lack of permanent employment ${ }^{33}$.

What has happened to BLACK society in Limon after it has been drained of important segments of its work-force? More jobs are now taken by the Whites of the highlands and the refugees (on the banana plantations, for instance) and the BLACK families are completely torn 
apart. This situation has currently affected its youth in a twofold manner: (1) those high school graduates who stay in Limon are working as stevedores, and those who continue their studies at the university, later opt for white collar jobs; but (2) once they have succeeded in securing a degree, these young people do not wish to return to Puerto Limon because of the lack of challenging opportunities. The number of single mothers has increased dramatically ${ }^{34}$, and crack cocaine is available for the asking (Prof. Greta Bennett, personal communication, December 28, 1992). Constant strikes are evidence of the social unrest the population is experiencing. Costa Rican officials claim that "the BLACKS are lazy by nature and they expect the government to do everything for them". ${ }^{35}$ The Limonese I talked to told me that nothing is being done by the government to prevent the spreading of drugs, to treat those who are addicted, to secure gainful employment for their youth, to solve the infrastructure problems created by the earthquake, to strengthen the Limonese BLACKS' cultural identity through regional education. On the contrary, they believe, there seems to be a general feeling of heightened racism against the ${ }^{36}$. The Limonese population is experiencing a serious weakening of links with their roots, a loss of their cultural heritage resulting from a growing trend that ridicules and brings into disrepute West Indian values ${ }^{37}$. No matter how bleak this picture is, however, one would have to admit that although BLACKS are a long way from becoming a substantial part of the competitive market in the country, the possibilities of doing so are much better today than they were only twenty years ago.

As mentioned earlier, during the second period that Michael Olien has outlined, that of the WEST INDIAN BLACK (1870-1948), English had a prominent position in the social and economic life of the region, more than merely as the language of instruction. Jamaican Creole was the communicative code in family and.communal life for the greater part of Limon's population. The Company used English as its official language and modus operandi for all transactions.

From the inception of the United Fruit Company (1899) until it folded (1942) on the Atlantic coast, a period of a little over 40 years elapsed. During this time, it is very likely that the Limonese BLACKS--who came mostly from Jamaica as has been seen, but who had been joined by other BLACKS from the Caribbean--consolidated into basically one language group. Although other varieties of West Indian English Creoles existed then, and still exist today, the more widely, natively-spoken Jamaican Creole developed a separate course in Limon, Limonese Creole. Since LC descends from Jamaican Creole (JC) it is similar to it in many respects. However, while JC is one of the most thoroughly treated English-based Creoles, few studies have shown a related English Creole in the context of a non-related-to-the-creole prestige language, Spanish (S) in this case.

Since during U.F. Co. times the prevailing pattern was the adjustment to West Indian life in Limon--not to Hispanic Costa Rica, and therefore there existed no pressure to learn Spanish--it seems justified to consider the existence of LC as a newly formed continuum of variation. The justification lies in the following considerations: BLACKS children heard their parents and friends speak JC, they received their education in English-speaking schools, they attended Protestant churches where services were conducted in English, they used an English Bible, the Company officials spoke English, frequent visitors came from Jamaica where Jamaican Creole and English were spoken, and the newspapers they read were from Jamaica 
and written in English. Furthermore at that time Limon Province was more BLACK than Spanish- white.

When the U.F.Co. abandoned its operations in the region (1942), English began to lose its prestige. The new dominating element was Costa Rican and Spanish-speaking. Large contingents of White people (which soon surpassed in size the number of BLACKS, as mentioned above) arrived in Limon. Since elementary education is compulsory in Costa Rica, Spanish was learned obligatorily. In the mid 40s, BLACK parents finally began to see the need for children to learn Spanish and encouraged them to attend Spanish schools.

Today LC is still extant as a creole of variation. Furthermore, the present contact between LC and American English, through tourism and the media, has started a process of decreolization of LC, i.e., creole features are being dropped to be replaced by those of the donor language. The linguistic situation described has given rise to a continuum of varieties whose speakers have command of a range from the most standard norm (Standard Limonese English,closest to the superordinate Standard English) to the least standard norm (farthest from the superordinate and closest to what was at one time Jamaican Creole), with the eventual outcome depending, among other factors, on the development of their desire for acculturation to the specific speech communities ${ }^{38}$. In idealized form the standard and the creole could be seen as two separate entities at the opposite poles of such a continuum, with the poles connected by a series of lects involving the admixture of creole and standard forms in systematic ways. Thus, as one moved closer to the standard end, one would encounter more standard forms, and there would be more creole forms as one moved closer to the other extreme. If the continuum were to exist, LC speakers closer to the creole pole would say/a di gwo/glossed as Standard English (SE) "I went," to indicate the past tense of the verb 'to go'; and they would say /ay wen(t)/ if they were closer to the standard end. As speakers moved into the area in between the two extremes they would use examples of both. This is an oversimplified description of a much more complex process, but the fact remains that the existence of LC as one entity in which all speakers are represented by variable usage may be posited.

The hypothetical standard speaker and creole speaker do not exist in Limon. Some speakers use many standard forms and a few creole forms too, or the other way around, depending on a variety of circumstances, but no one speaker uses exclusively standard features all the time, or creole features all the time. This variation in usage is present in LC phonology, lexicon, syntax, and semantics. Moreover, LC speakers of today are in the process of restructuring their linguistic rules, incorporating more and more elements of Spanish, the prestige language of the country, into their grammars ${ }^{39}$.

\section{Language and Identity: Maintenance or Shift}

Linguistic diversity constitutes a threat to the broader political order of a nation. Usually, a commonly shared tongue is seen as a vehicle for the maintenance of the perceived unity of purposes and needs shared by the country's inhabitants. Thus it is hardly surprising that in order to develop and keep the political loyalties in place, the state will run programs for the national language to be used by the entire population. 
In Costa Rica, if the degree of success of the national literacy campaigns is to be measured by the increasing number of people who can speak, read, and write Spanish in the Province of Limon (and as a result of the 1953 legislation, to ban English education from the region completely), then the efforts of the Ministry of Education have proved effective. The degree of illiteracy is relatively low in the Province of Limon as compared to the rest of the country ${ }^{40}$.If linguistic differences form a major obstacle to assimilation--even though ethnic and racial groups can perpetuate themselves without distinctive languages--by reducing linguistic differences the nation fosters ethnic merger. Although no official figures are available, it appears that there have been great increases in the proportion of ethnically--and linguistically-mixted marriages between ingroup and outgroup. This gives the high-status linguistic variety (Spanish) a better chance of surviving as the language of the home, and hence of caretakerchild interactions. Moreover, a group that does not maintain its identity will be more likely to give up its language as well.

In 1974 following an initiative from the then Secretary of Education, Lic. Fernando Volio, Limon saw a revival of the government's interest in the teaching of English at the grade school level, using the students' fluency in LC as a basis to make the quick transition to English. Teacher training seminars were held in the region under the direction of a Ministry of Education representative, Lic. Eulalia Bernard. However, the pilot project that was to be implemented was aborted as it elicited strong negative reactions from parents and teachers who could not see the relationship between LC and English as a positive one. The overall battle towards Limon's integration into the mainstream of Costa Rican society was seen as requiring Spanish, not English. Educators and parents alike felt than LC and English would hinder their fight against isolation from the rest of the country. In the end, all attempts to convince the parties involved of the need to capitalize on the children's LC knowledge failed. Those Limonese in influential positions in the educational system even refused to admit the existence of $\mathrm{LC}^{41}$.

As people acquire a language, they also acquire attitudes and beliefs toward that language and toward other people's languages. These are shared by the members of the linguistic community and form an integral part of the culture. As with most creoles, LC speakers have fallen prey to the widespread belief that /mekaytelyuw/ is "broken or flat English," a "patois," a "dialect" but not "a real language." Proof of this, they claim, is that "it is not a written language" and that "it has no grammar."

With a writting tradition languages acquire standardization, norms are set by recognized authorities and they are printed in books and taught in schools. Thus languages which are transmitted exclusively through the speech of individuals, without the formal frame which education gives to language variants, make their speakers focus on the reality of variation. In the limonese situation certain feelings of it being a "second-class language" (and consequently, of their being "second-class citizens") are attributed to LC by its speakers, and their very deeply-seated prejudices against it are apparent. It is associated with what they believe is their own negative self-portrayal: lack of education, primitive ways, superstitious beliefs, poverty, slavery, and a general inadequacy for acquiring a high social status.

Contrary to their deprecatory self-image, the Limonese have a highly verbal culture. Each day of their life is filled with words and the clever use of language is greatly appreciated. 
Until recently, classification of an individual as to personality and character within the community was partly based on the LC speech behavior of that individual and one's status depended partially on one's ability to perform verbally in LC. Limonese Creole, Standard English, and Spanish occur in the framework of a triad of cultural patterning made up of West Indian, British and Costa Rican cultures. This underlying trinity is disguised and covered up through what is both a historical process and an ongoing symbolic technique of taking on dominant cultural forms and remodelling them, so that the three cultural strands are woven into a complex garment of cultural and linguistic expression ${ }^{42}$.

When I originally conducted field work in Limon, as I approached them, most Limonese smiled and giggled, then claimed they could not speak /mekaytelyuw/, halfamazed, half-scornful of a foreigner coming to study the grammar of a language they thought had no grammar. All the time they were curious and puzzled about the intrusion of a linguist who presumed their language well worth studying. They were critical of the attention given to LC, which they believed should be replaced in most situations by "correct" English or Spanish. LC speakers were apologetic (saying their language was "bad" English), and Jamaican-educated grandparents abhorred the creole spoken by their "grands". They blamed themselves for not having insisted on their children attending English school to acquire 'proper' English and to learn to respect it as had their parents and ancestors. However, it is obvious that fluent LC speakers enjoy/mekaytelyuw/. Through decades of White colonization and domination they have come to keep to themselves the love they feel for their language and their culture ${ }^{43}$.

As to the actual use of LC, the chart above (Table 3) exemplifies the most common linguistic exchanges which call for either LC, Spanish or Standard English (Herzfeld 1980: 11, here revised), but bearing in mind that there are a number of factors which intervene in language choices (such as ethnic composition of the group, topic, age and gender of interlocutors).

\section{Conclusions}

As mentioned above, it appears than even the most fervent desire on the part of grandparents to retain LC may eventually be overcome by the promise of social and economic advancement, in both the public and private sectors, offered by the mastery on Spanish. Moreover, the number of social contacts in which speakers use LC seems to be steadily declining. The evidence gathered so far shows that domains specific to the minority language variety have often been encroached upon by Spanish, the prestige language; actually, only if those domains were identified as stable, would a condition of bilingualism possibly prevail. Without continued representation of the language and group members in a variety of institutional settings such as educational systems, media, religion, and work, the etholinguistic vitality of the group is at great risk, since the influence of the home is not sufficient to preserve LC (particularly considering that the time children and their family spend at home nowadays has greatly diminished).

Stages in the process of languages shift fall into a continuum ranging from language conservation (language life) to language loss (language death). However, I would argue that the 
life-death metaphor does not serve the study of language usage very well. The more meaningful question is one of ethnicity, i.e. How important is it for a member of this minority to be a BLACK Limonese? And does LC express that ethnicity?

The point has been made already that few other elements involve the emotional attachment that oral communication does in members of an ethnic group; however, the death of a language does not inevitably mean the total disappearance of a group's identity. One of the common circumstances for language death is that of the gradual disappearance of its speakers; in that case, however, the group's identity could be kept intact until its last speaker dies. That is not what concerns us here at this time. The LC scenario is, rather, a case of language contact and conflict (one superordinate language actively threatening to supplant the other), in a racially and culturally distinct speech community which is now somewhat spread out geographically and which may succumb to "the intrinsic hostility of the technology-based infrastructure of modern civilization" (Edward 1985: 49).

The sociolinguistic process outlined above would seem not to bode well for the survival of LC. However, as Fishman has suggested, the question to be asked is "Do they love it in their [the speakers'] hearts?" (quoted by Huffiness 1991: 9). I would venture to say that if, in light of its sociohistorical background, the group values its identity--particularly in the face of present socioeconomic pressures towards the universalization of culture--it is likely that LC will prevail against all odds.

As to future research on this topic, I believe that the optimal approach in the measurement of language shift would require a longitudinal analysis of the language practices of the group. However, I would like to suggest that unless future research considers the sociolinguistics history of the speakers (and within in their ethnic identity) as a relevant element in such a study, the model will not make a contribution to intelligent debate on the subject.

\section{Notes}

1. I am indebted to Professors María Eugenia Bozzoli, Akira Yamamoto and Daniel Breslauer, and Ms. Kathy Shea for valuable comments on an earlier version of this paper.

2. Of all the powerful elements of group identity (ethnicity, nationalism, and the relationship between them), Edwards (1985: 22) claims that "the most important ingredients are the subjective sense of groupness and the continuation of group boundaries." He considers that these two are indeed related, but since certain aspects of group culture are always subject to change, the continuing identity must depend upon elements which transcend any purely objective markers. "This is not to say," he continues, "that visible markers are dispensable, but rather that the presence if any particular marker is not essential."

3. In this paper, it is impossible to consider the full range of complex relations which exist between the status of a language and such factors as literacy, urbanization, industrialization, political and economic power, religion, geography, and demography, among many others which definitely intervene in a two-way causal relation between language and identity.

4. Carvajal and Driori (1987: 19, my translation) explaining the depressed state of the local economy state that

At present the Limonese region developmental model could be summarized by saying that the benefits of the local economic 
activities either flee the region via multinational corporations or else favor directily the public treasury via taxes.

5. Edwards' more complex definition (1985: 10) suggests that:

\begin{abstract}
"Ethnic identity is allegiance to a group--largeor small, socially dominant or subordinate--with which one has ancestral links. There is no necessity for a continuation, over generations, of the same socialisation or cultural patterns, but some sense of a group boundary must persist.This can be sustained by shared objective characteristics (language, religion, etc.), or by more subjective contributions to a sense of 'groupness', or by some combination of both.Symbolic or subjective attachments must relate, at however distant a remove, to an observably real past.
\end{abstract}

Definitions of "ethnicity," of course, about as do the criteria considered adequate for defining a collectivity as an "ethnic group," and as distinctive from a "racial group." In this paper, I will adopt the view (based on Turner 1978) that an ethnic unit is formed by those individuals who say they belong to ethnic group A rather than B, and are willing to be treated and allow their behavior to be interpreted and judged as A's and not B's.

6. Fishman states that "paternity" is a central experience around which all others can be clustered, and that

it deals with the recognition of putative biological origins and, therefore with the hereditary or descent - related "blood," "bones,""essence," "mentality," "genius," "sensitivity," "proclivity" derived from the original putative ancestors of a collectivity and passed on from generation to generation in a biokinship sense.

In other words, heritage determines one's ethnicity. From the point of view of a person's experience, this "paternity" is probably seen as the key (referred to as "primordial" by Geertz 1963) to that individual's ethnicity, no matter whether it is played down, or even denied to escape it.

7. Fishman (1977: 20) claims that although distinct from each other, "paternity" and "patrimony" may reinforce each other since they are constantly interacting in ethnicity, as poles along a continuum. The difference is that while ethnic patrimony is learned, paternity is inherited from ancestry. In other words,

The paternity dimension of ethnicity is related to questions of how ethnicity collectivities come into being and to how individuals get to be members of these collectivities.

The patrimony dimension of ethnicity is related to questions of how ethnic collectivities behave and to what their members do in order to express their membership. The former maintains that one must either be or not be of a given ethnicity [...]

The latter recognizes that one either may or may not fulfill the obligations of ethnicity.

8. Interestingly enough, it seems that these acquired characteristics of one's identity (Fishman's "patrimony") are the key by which outsiders perceive a group's identity (Giles 1977: 326).

Johann Gottfried Herder (1744-1803), the author of Ueber den Ursprung der Sprache, argued in favor of the human innately-endowed capacity of reason and speech, which ultimately links an individual, through his/her mother tongue, to the expression of the nationality's soul and spirit.

9. Regina Harrison (1989: 15) tells the story of Gregorio Condori Mamani, a monolingual Quechua speaker when he served in the Peruvian army many years ago: 
Up until that time [entering the army] I didn't speak Spanish and I scarcely left there speaking Spanish; I almost spoke some Spanish at the end. The lieutenants and the captains didn't want us to speak in Quechua (runa simi).

"Indians, dammit! Spanish!" they used to say. With that, they make you speak Spanish in classes.

10. This terminology is borrowed from Lieberson (1981: 84)

By 'indigenous" is meant not necessarily the aborigines, but rather a population sufficiently established in an area so as to possess the institutions and demographic capacity for maintaining some minimal form of social order through generations.

11. Diglossia is a linguistic phenomenon defined as the existence of separate languages with socially allocated functions for each one.

12. When two populations begin to occupy the same habitat but do not share a single order, the way in which political and economic conditions are changed will determine whether conflict or a quasi harmonious assimilation will occur (Lieberson 1981: 86).

Initially at least, the indigenous subordinate group will try to carry on with its established set of institutions, keeping at some spatial distance from the superordinate group. If it does not succeed in its endeavors, conflicts will arise. In Latin America, these led to the decimation of the subordinate group's sources of sustenance and disrupted linguistic, religious, and tribal forms or organization. Although at a slow rate in some cases, the language and identity of those who survived has been or is being shifted. This is the linguistic process which has taken and is taking place in most Latin American countries of subordinate indigenous populations.

13. Its uniqueness is due to geography, fortuitous historical events, and the sizable number of the linguistic minority; as a consequence, Guaraní has been recognized as one of the two official languages of Paraguay. The Paraguayan example illustrates a superordinate group (the Spanish elite) in contact with the Guarani (an indigenous subordinate group--the masses, a powerless minority in spite of its size). Different domains in the life of the community are handled by the tow linguistic varieties in a complementary (diglossic) fashion: Guaraní is the language of intimacy, whereas Spanish is more likely to be used with mere acquaintances, thus formal relationships or tipics require Spanish, while jokes are told in Guaraní. (Peñalosa 1981: 113, Rubin 1985: 111, Rona 1971: 277).

14. This is the case of two groups forming a single society in which there is both bilingualism and diglossia.

15. By "rapid," I mean a substantial change in the course of only a few generations.

16. Needless to say, "European" and "African" are oversimplistic generalizations, which comprise groups of peoples of diverse origins. Also, the process here explained has taken place all over the world and does not apply exclusively to Africans and Europeans.

17. There are several explanations of the origin of creole languages. Basically they fall into two separate views: the monogenetic and the polygenetic theories (Herzfeld 1978: 72).

18. The five indigenous languages referred to are Boruca, Bribri, Cabécar, Guatuso, and Térraba. Guaymíes are recently arrived Indians from Panama. They have made their way to Costa Rica from Chiriquí to Coto Brus via the Península de Osa. 
19. Limonese Creole is called /mekaytelyuw/ or /mekatelyuw/ by its speakers. It comes from Jamaican Creole in which "Make I tell you something" is equivalent to Standard English "Let me tell you something." The broad transcription used here is a phonemic system accessible to a non-initiated reader.

20. The Chinese were required by law to return to China after they had fulfilled their contractual obligations that originally brought them over to Costa Rica (Limon). They were considered "undesirable persons" (Olien, 1965: 5-6). But many stayed on and their relatives continued to flow into the country illegally (as stowaways) for a number of years.

21. In Limon, "Coolies" designates descendants of Indian (Hindu) immigrants who later racially mixed with BLACKS.

22. The ethnic composition of the population of Port Limon in the 1950s was approximately made up of $42 \%$ BLACKS, $46 \%$ Whites, and 12\% Coolies, Chinese, and Amerindians. The latest figures for the Atlantic region (which includes the Province of Limon) are as follows:

$\begin{array}{lr}\text { Atlantic Region: Population by Ethnic Groups (1964) } \\ \text { Ethnic group } & 1984 \\ & \\ \text { Hispanic-Latins } & 117,792 \\ \text { Blacks } & 58,517 \\ \text { Ameridians } & 6,000 \\ \text { Chinese } & 5,000 \\ \text { Total } & 197,316\end{array}$

Source: Carvajal and Driori (1987: 43)

23. It is in the first (colonial) period referred to that the first importation of African BLACKS to Costa Rica took place. Most were slaves--the number was never high, and a few became free men early in Costa Rican history. Some might have even run away, (Meléndez, 1972: 23, i.e., cimarrones), since they were owned by highlanders in absentia.

24. Mamita Yunai is the title of a book by the Costa Rican novelist Carlos Luis Fallas (1941: 246); he explains that this is the name by which the Spanish-speaking workers referred to the UFCo. Mamita, of course, is a diminutive of mamá (mother) and Yunai stans for the way the Costa Rican pronunciation of "United" sounded.

25. At one time, when I was conducting research in Limon in 1975, a Taller Artístico de Limón was taking shape. There were theater groups and local dance groups, newly conceived means of expression of the Limonese self, that young friends of mine helped create. At that time also, a Comité Cívico de Limón, functioned as a self-appointed body of "elected citizens", concerned with local issues as they related to the need for action by the national government.

26. JAPDEVA (Junta de Administración Portuaria y de Desarrollo Económico de la Vertiente Atlántica) is often called "Blackdeva" in the usual good vein of Limonese humor, because of the number of BLACKS employed there. St. Mark's is a private school run by the Episcopal Church; MUCAP (Mutual de Cartago de Ahorro y Préstamo) is a local branch of a private agency which provides housing loans.

27. Cosmopolitan it is indeed, if one takes into account the many different churches represented in Limon, the various ethnic groups, and the different languages one hears on the streets. 
28. Rough estimates for Puerto Limon, provided by Professor Greta Bennett (personal communication, December 28, 1992) claim a 60\% majority of Whites and Mestizos; and 35\% Blacks; the remainder 5\% would be composed of native Amerindians, Chinese, Zambos, and Coolies.

29. Unfortunately, the troubles of Nicaraguan political refugees who sought asylum in camps in Costa Rica (one of them was in Limón) did not end when they crossed the border. In addition to the emotional, psychological and social scars which they suffered by their forced migration from Nicaragua and their loss of loved ones and property, once in Costa Rica they were subjected to confinement in substandard housing conditions and to an increasing dependency on outside assistance.

Unhealthy "mass rules" for family life eroded their self-worth, creating identity crises. (Pacheco, 1989: 6272).

30. Only thirteen years ago, when I was conducting a similar sociolinguistic study in near-by Bocas del Toro (Panamá), I frequently travelled to Port Limon in buses in which I was one of the few White passengers.

31. BLACKS do not work in plantations any longer since their slavery experience is too fresh in their minds. As an aside, it may be noted that the media often remarks (News television program, December 30,1992) on the lack of control the government has exercised over the banana companies. They have hired foreign labor, but they are not fulfilling their contractual obligations with the workers, in regards to their schedules, living conditions, and health standards.

32. As Hadley (1973: 20) puts it,

The question still remains to be answered, however, why the present day West Indian proletariat have in so many instances failed to acquire the psychological adjustments necessary to successful adaptation to a competitive society.

He partially answers it by saying that to change the mental attitude of ex-slaves for whom work is an imposition and a burden to one in which it means the honest procurement of food, shelter and clothing, society should have provided Blacks with oportunities to realize these ambitions. It is easy to see that society has not provided them with the means to achieve satisfaction from an entirely new set of values.

33. Today, both men and women are being channeled to the U.S. by money-making agencies in Limon which procure them employment; the men mostly come as sailors and the women, though in much smaller numbers, as nurses (nannies) or domestic servants.

34. Children in Limon have always been thought of as security for the future; they were seen as possible means of support in old age. Even children from other relatives or friends were taken into families. When I lived in Port Limon, twenty years ago, there were virtually no abandoned BLACK children in the city. The local orphanage hosted some 40 children who had been abandoned by their parents; only one of them was BLACK. Today at the Centro Cúpula, the Limon branch of a Canadian-run organization for abandoned children, out of 12 children, 4 are Nicaraguan; the others are BLACK LIMONESE.

35. This quote came up in several conversations held with "liberal-minded" Costa Ricans,(December 1992: 2130 ), who openly admitted to me that they are "racists".

36. Several radio and T.V. programs are now openly airing racial jokes. In San José, on Sunday mornings at 9:00 a.m. Radio Columbia features a program called "La Patada" in which a White Costa Rican who calls himself "Sweetie" imitates LC and the Spanish dialect spoken by Black Limonese. Channel 7 on T.V. had a live show of the carnival festivities during the Christmas-New Year celebrations. A Costa Rican bull-fight teatured a White Costa Rican, Lucho Ramírez, acting out a Black Limonese under the fictional name of "Patti". And finally, in Limon itself, Radio Casino has a Spanish "Ms. Matti", on Saturday morning at 9:00 a.m., imitating the Limonese in a program called "La Hora Brava." Some of the jokes I was told recently, which succinctly capture the poor taste of the racial slant which seems to be "in," consistent with the mood of the country, go as follows: 


\begin{abstract}
-What should you throw to a BLACK woman who is drowning?
-Her husband and child.
\end{abstract}

\author{
-Why did Liberación [the social democratic party] lose the national \\ elections in Limon? \\ -Because they [the Liberación politicians] promised jobs to all \\ Limonese. \\ -What did the parrot tell the crow? \\ -Good morning! (heavily accented). As the crow did not reply, the \\ parrot added: \\ -He must be the only BLACK who does not speak English.
}

37. As an aftermath of the earthquake, a building which had housed a West Indians lodge for 100 years collapsed. Curious neighbors dug out of the rubble a skull and other objects, which they said were a Bible, candles, some coffin-looking boxes and some bones. No sooner did this information hit the press that myths of satanic cults were linked to the finding, thus hurting the reputation of a solid West Indian institution. (La Nación, Revista Dominical, 9 de febrero de 1992: 10-14).

38. The "creole continuum" concept was introduced in creolistics by De Camp (1961: 82) as a model for studying Jamaican Creole. Bickerton's work (and that of other scholars) is based on analyses of variation along creole continua. However, lately it has become somewhat controversial because of presumed circularity in its usage.

39. The linguistic process called code mixing or code switching, i.e. incorporating Spanish forms into LC is apparent in the sample transcription of the language below (Herzfeld 1983: 135).

Interviewer--Yuw get lik tuw?

Informant--/Shor man/ diy taym did rof... plentiy pikniy... wa town big man... wen dem did smahl dem pyeren alwez lik dem... an a neks tin /layk/ wan taym/wan taym miy an a bway av a trobl/sow miy did av a kozin/ im waz a baksa/ kom from Panama/ an im layk echar carbón pan yuw no?/ dat yuw mos fayt an ahl dem tin/ an im waz lernin miy fayt a likl no?/ sow now yuw av a bway/ bowt dem waz twyn/ emmm/ dem was twyn/ di twyn dem fyeba tugeda/ bot in a twyn yuw alwez av wan biga dan wan/ so miy did afi nyel wid diy likl wan/ so miy gow an tel miy kozin no? /emmm/ "lisin/ now gari/ an so an/ an/ an a gow tomp im"/ "ya/ man"/ may kozin tel miy/ "tomp im eniy taym yuw siy im"/ so di iyvnin wiy sidown pan di saydwahk an wiy siy di bway komin down/ so a se "ey/ kozin/ siy im a kom de?"/ im se/ "arayt/ wen im kom yuw gowim retar/ a gowin tahk wid im and den yuw get op an jomp rown im"/ an so diy bway kom/ an miy neba nwo waz diy biga wan/so diay/ miy fiyl matón layk hel/ bway/ an miy kozin tel im ahl kayn a fuwlishnis/ miy staht tu jomp rown diy bway now/ an jomp rown an toch im prity/ dem bway yel/ an klapin/ an diy bway siyrias lauk hel/ bika in did fraytin/ bikaz im no now miy/ an im no nwo miy ay notin wid im...l

A trancription into English would read:

Interviewer--Did you get licked too?

Informant--Sure man, the times were rough... many children... who turned big men... when they were small, their parents always licked them... and something else [another thing], like one time, one time [once] me and a boy had a problem [trouble], so I had a cousin, he was a boxer, [he] came from Panama, and he liked to echar carbón upon you, no? That you must fight and all those things. And he was teaching me [how to] fight a little, no? So now, there was [you have] a boy, but they were twins, hmmm, they were twins, [the] twins, they look like each other [they favor together], but in twins you always have one bigger than the other one, so I had a problem [nail] with the little one, so I went and told my cousin, right? hmmmm, "Listen, now, Gary, and so and, and, and I am going to stamp him," "Ya, man," my cousin told me, "stamp him any time you see him," so [in] the evening we sat down upon the sidewalk and we saw the boy when he was coming down, so I said, "Hey, cousin, do you see him coming there?" He said, "All right, when he comes you are going to retar [him]. I am going to talk to him and then you get up and jump 
around him." And so the boy came, and I didn't know [never knew] it was the bigger one, so diay I felt matón like hell, boy, and my cousin told him all kind of foolishness, I started to jump around the boy now, and jumped around, and knocked him hard [touched him pretty], the boys yelled, and [they] were clapping, and the boy was serious like hell, because he was frightened, because he did not know me, and he didn't know I had something against him...

40. It was $6.6 \%$ in the Central Province and only $7.9 \%$ in Limon according to the census taken by the Dirección General de Estadísticas y Censos (1973: 43-48).

41. These objections are strongly reminiscent of the same feelings aroused in the U.S. when BLACK English was first "discovered" as a valid dialect by linguists such as Labov, Wolfram, Schuy and Fasold in the 60s, as its use was suggested as a communication tool to teach BLACK children at school.

42. For example, behind a mask of carefree glee, people maintain a valued quality of hardness. It amounts to a positive acceptance of conditions in which they find themselves. Children are not entertained by readings of Grimm's stories--where the prince marries the princess and they live happily forever after--but instead are trained survival skills through Anancy stories. In them Brother Nancy, the spider (which like other animals in the stories assumes human characteristics) is a trickster who steals, cheats, deceives his 'friends,' and breaks all of society's ethinal codes. He ends up being deservedly punished. In the same vein, small children who fall and hurt themselves are bounced up and down as long as necessary until they laugh. A strong form of teasing is likely to be used if one shows signs of weakness; emotional consolation is hard to come by. If it is overtly needed, a person will be teased until the individual is made the stronger for it. This upbringing drives people in varying degrees inside themselves.

43. As one of my informants (interview with F.H., field notes, June 15, 1974) an eighteen year old senior in high school, put it.

/e neks prablem in awe langui ${ }^{2}$ iz dat az aal de lyediz want to konserbyet de languij/ / wot wi taak down yer in limon/ ay wud layk fa wiy tu hak kwik bowt it/ tu rayt buk dem/ far if wiy dwon duw dat/ de languij wat wiy taak wil miks wid spanish/ bikazin ay siy dat plentiy taym... e gruwp ev os taaking/ an somwan/ layk se/ wud se/ "dis profesa dwon gii lesen gud"/ wiy wud se "dis profesor..." an wa wiy duwin rayt der iz miksin de langui jen... if wi grwo op an marid an av sonz en wi taak tu dem dat we/ dats de wye dem wil lern tu taak/ an sow de langui j.../ far in e fiftiyn tu twenti yez mor it wil bi bryek op in a miks languij/ / en wi wudn av now eksistent ev dis/ wat wi taak rayt now.../

[Another problem in our language is that, as all the ladies want to preserve the language, what we talk down here in Limon, I would like for us to act quickly about it, to write books, for if we don't do that, the language that we talk will mix with Spanish, because I see that often... a group of us is talking, and someone, namely, would way, "This professor doesn't teach well," we would say "This profesor..." and what we are doing right there is mixing, the languages and... if we grow up and marry and have sons and we talk to them that way, that's the way they will learn to talk, and so the language... for in fifteen to twenty years more it will be broken up in a mixed language, and we wouldn't have any trace of this, what we are speaking right now...]

\section{Bibliography}

Apple, R. and P. Muysken. 1987. Language contact and bilingualism. London: Edward Arnold.

Augelli, John P. 1962. "The Rimland-Mainland Concept of Culture Areas in Middle America." In Annals of the Association of American Geographers. Vol. 52, 119-129. 
Bickerton, Dreek. 1975. Dynamics of a Creole System. Cambridge: Cambridge University Press.

Bryce Laprote, Roy S. 1962. "Social Relations and Cultural Persistence (or Change) Among Jamaicans in a Rural Area of Costa Rica." Unpublished Ph. D. dissertation. Institute of Caribbean Studies, University of Puerto Rico.

Carvajal, Guillermo and Israel Driori. 1987. "La diversidad étnico-cultural en la región Atlántica y los problemas de integración socio-espacial al contexto regional costarricense." In Revista Geográfica. 107: 19-43.

DeCamp, David. 1961. "Social and Geographical Factors in Jamaican Dialects". In Creole Language Studies II, ed. by Robert B. Le Page. New York: St. Martin's Press.

Dow, James R., ed. 1991. Language and Ethnicity. Amsterdam: John Benjamins.

Edwards, J. 1977. "Ethnic Identity and Bilingual Education." In H. Giles, ed. Language and Ethnicity and Intergroup Relations London: Academic Press, 253-282.

1985. Language, Society and Identity. Oxford: Basil Blackwell.

Fallas, Carlos Luis. 1941. Mamita Yunai, San José, Costa Rica: Editorial Soley y Valverde.

Fishman, Joshua A. 1989. Language and Ethnicity in Minority Sociolinguistic Perspective. Clevedon, PA.: Multilingual Matters Ltd.

1986. The Rise and Fall of the Ethnic Revival. Berlin: Mouton de Gruyter.

.1977. "Language, Ethnicity, and Racism." In Georgetown University Round Table on Languages and Linguistics 1977 ed. by Muriel Saville-Troike. Washington: Georgetown University Press.

1972. Language in Sociocultural Change. Essays Selected and Introduced by Anwar S. Dil. Stanford: Stanford University Press.

Giles, Howard, ed. 1977. Language, Ethnicity and Intergroup Relations. London: Academic Press Inc.

and Bernard Saint Jacques, eds. 1979. Language and Ethnic Relations. Oxford: Pergamon Press.

Buckingham: Open University Press. 
Gudykunst, William B., ed. 1988. Language and Ethnic Identity. Clevedon, PA.: Multilingual Matters Ltd.

Gumperz, J.J. ed. 1982. Language and Social Identity. Cambridge: Cambridge University Press,

Haarmann, Harald. 1986. Language in Ethnicity: a View of Basic Ecological Relations. Berlin: Mouton de Gruyter.

Hadley, C.V.D. 1973. "Personality Patterns, Social Class, and Aggression in the British West Indies." In Consequences of class and color: West Indian Perspectives, ed. by David Lowenthal and Lambros Comitas. Garden City, New York: Anchor Press.

Harrison, Regina. 1989. Signs, Songs and Memories in the Andes, Austin: University of Texas Press.

Herzfeld, Anita. 1978. "Tense and Aspect in Limon Creole: a Sociolinguistic View Towards a Creole Continuum." Unpublished Ph.D. dissertation. Lawrence, KS: The University of Kansas.

.1980. "Bilingual Instability as a Result of Government Induced Policies." In ITL: Review of Applied Linguistics 48: 1-20.

Holm, John, ed. 1983. Central American English. Heidelberg: Julius Gross Verlag.

1988. Pidgins and Creoles. Volumes I and II. Cambridge: Cambridge University Press.

Huffines, Marion L. 1991. Pennsylvania German: "Do they love it in their hearts?" In Language and Ethnicity: Focusschrift in honor of Joshua Fishman, ed. by James R. Dow, 9-22.

Le Page, Robert B. 1960. "An Historical Introduction to Jamaican Creoles." In Creole Language Studies. ed. by R.B. Le Page, London: MacMillan, 3-124.

Lieberson, S. 1981. Language Diversity and Language Contact. Essays selected and introduced by A.S. Dil. Stanford: Stanford University Press.

Meléndez, Carlos. 1974. "Introducción a la Cultura Negra." Curso de Capacitación para Educadores de la Provincia de Limón, Siquirres, Setiembre 23-24, 1974. San José, Costa Rica: Ministerio de Educación Pública.

Olien, Michael D.n.d. (1965?) "The Negro in Costa Rica: an Historical Perspective." Mimeographed copy. 
1972. "Ethnohistorical Research on Colonial Black Populations in Costa Rica." Paper prepared for the Latin American Panel, American Society for Etnohistory Annual Meeting. Boston, Mass.: Boston University.

1977. "The Adaptation of West Indian Blacks to North American and Hispanic Culture in Costa Rica." In Old Roots in New Lands, ed. by Ann M. Pescatello. Westport, Connecticut: Greewood Press, Inc.

Pacheco, Gilda. 1989. "Nicaraguan Refugees in Costa Rica: Adjustment to Camp Life." Washington, D.C.: Georgetown University, CIPRA.

Peñalosa, Fernando. 1981. Introduction to the Sociology of Language. Cambridge, Mass.: Newbury House Publishers.

Rickford, John. 1987. "Language Contact, Variation and Diffusion: Microlevel Community Perspectives." In Georgetown University Round Table 1987, ed. by Peter Lowenberg, 25-44.

Roberts, Geoge. 1957. The Population of Jamaica. Cambridge: Conservation Foundation at the University Press.

Rona, José P. 1971. "The Social and Cultural Status of Guaraní in Paraguay." In Sociolinguistics, ed. by William Bright. Berlin: Mouton.

Rossi, Anacristina. 1992. La loca de Gandoca. San José, Costa Rica: EDUCA.

Rubin, Joan. 1985. "The Special Relation of Gaurani an Spanish in Paraguay." In Language of Inequality, ed. by Nessa Wolfson and Joan Manes. Berlin: Mouton.

Scherer, Klaus R. and Howard Giles, eds. 1979. Social Markers in Speech. Cambridge: Cambridge University Press.

Simms Ennis, Giselle. 1990. "Un análisis sociolingüístico de las esferas de uso del inglés de Limón en hablantes que residen en San José, Costa Rica, y algunas actitudes de los hablantes y de los descendientes de hablantes del inglés de Limón, que no lo hablan, con respecto a esta lengua". Unpublished Master's Thesis. San José, Costa Rica: Universidad de Costa Rica. 
Smit, A. 1971. Theories of Nationalism. London: Duckworth.

Stewart, Watt. 1964. Keith and Costa Rica: a Biographical Study of Minor Cooper Keith. Albuquerque: The University of Mexico Press.

Thorton, J. 1992. Africa and Africans in the Making of the Atlantic World, 1400-1680. Cambridge: Cambridge University Press. 